Joachim Mugdan

\title{
Grammar in Dictionaries of Languages for Special Purposes (LSP)
}

\begin{abstract}
In general monolingual and bilingual dictionaries and in the lexicographical literature on them, grammatical information is given a growing amount of attention. By contrast, grammar plays a rather minor role in LSP dictionaries although many users need a good deal of grammatical guidance in the production and reception of LSP texts.
\end{abstract}

\section{Introduction: Grammatical information in dictionaries}

\subsection{What is grammatical information?}

A typical dictionary definition of dictionary runs: "a book that gives a list of words in alphabetical order with their pronunciations and meanings" (LDOCE). In actual fact, most dictionaries also provide information on areas other than phonology and semantics - and so does the work from which the above explanation is taken: LDOCE is one of the British dictionaries for foreign learners which strive "to give as much useful information as possible concerning idioms and syntax", as the compilers of the first and best-known representative of this genre put it (ALD, iv). It is often such syntactic information that lexicographers have in mind when they speak of "grammar in the dictionary". Under this heading, the editors of LDOCE explain their codes for verb patterns, countable and uncountable nouns, positions of modifiers etc. (xxviii-xxxvii), whereas "types of word" (i.e. parts of speech) and "inflections" are discussed elsewhere (xiv-xv; xxii-xxiv). Similarly, a book entitled "Grammar in English Learners' Dictionaries" deals almost exclusively with syntax (esp. verb complementation); part-of-speech labels and information on inflection are mentioned only in passing (Lemmens/Wekker 1986). This tendency to equate "grammar" with syntax may be understandable in the case of a highly analytic language like English, but in a wider context such an interpretation would be too restrictive. For the present purpose, the term shall refer "to a level of structural organisation which can be studied independently of phonology and semantics, and generally divided into the branches of syntax and morphology" (Crystal 1985, 141). 
In an article devoted to grammar in the dictionary, Jackson distinguishes four kinds of grammatical information in dictionary entries:

"Firstly, there is information about the inflections that a lexical item might have [...]. Secondly, each item in the Dictionary is traditionally provided with a 'partof-speech' or 'word-class' label, e.g. 'noun','preposition'. [...] Thirdly, a dictionary entry may be provided with information of a more explicitly syntactic nature; for example, verbs are traditionally marked as 'transitive' or 'intransitive'. [...] Fourthly, grammatical - especially syntactic - information may be provided implicitly or covertly by means of the illustrative examples that may form part of a dictionary entry." $(1985,54)$

It should be noted, however, that examples furnish essentially the same type of information as explicit codes or labels. What differs is the form in which this information is given - and the dichotomy explicit vs. implicit does not suffice to characterize the many forms that syntactic information can take (cf. also Mugdan 1985b, 220f). For example, a particular use of the verb crowd could be indicated by

- [X9, esp. IN] (LDOCE)

$-\mathrm{V}+\mathrm{O}+\mathrm{A}($ in/into $)(\mathrm{COBUILD})$

- to $\sim \mathrm{sb} / \mathrm{sth}$ into sth (cf. PONS E-D s.v. wrest: to $\sim \mathrm{sth}$ from $\mathrm{sb} / \mathrm{sth}$ )

- if you crowd people or things into a place, [...] (COBUILD)

- to $\sim$ furniture into a room (PONS E-D)

- He helped his dad and brother crowd the animals into the truck (COBUILD)

We should therefore refine Jackson's description and introduce a twofold classification according to both content and form. The latter will not be discussed here (but cf. Mugdan 1983 and in press a on inflection, Bergenholtz 1984a and 1984b on parts of speech and syntax). As far as content is concerned, we are left with three areas: word class, inflection and syntax. Since a part-of-speech label "provides basic information about the syntactic operation of a lexical item" and is "an instruction about the kinds of inflections that are appropriate to the lexical item" (Jackson $1985,55)$, one could argue that it is nothing but a specific form of inflectional and/or syntactic information. But statements like "buy is a verb" still differ significantly from both "the past tense of buy is bought" and "buy can be used ditransitively" so that it seems appropriate to regard the specification of word-class (and, in the case of nouns, gender or noun class) as a separate type of grammatical information.

There is one further area of grammar that Jackson fails to mention: word formation. Consider, for instance, the microstructure of the following entry in LDOCE: 
Example 1

Although the status of "- - $\mathbf{l y} a d j "$ is not entirely clear, one could interpret it as a piece of information about the derivational properties of steep. If we consider that "grammar in the dictionary" need not be confined to components of individual entries (cf. 1.2), it will become even clearer that word formation belongs to our subject, too (cf. Mugdan 1985a).

\subsection{Where can grammatical information be found?}

As we have seen, a dictionary entry may contain information on the word class, the inflectional forms, the word formation patterns and the syntactic behaviour of a certain lexical item. It is usually said that the Dictionary deals with such "isolated facts", whereas "general laws" come into the domain of Grammar (e.g. Sweet 1892, 7; Jackson 1985, 53; here, Grammar with a capital $G$ does include phonology, semantics etc.). One can, however, not describe "isolated facts" without presupposing some "general laws". Firstly, the grammatical terms which are used in a dictionary reflect certain theoretical assumptions. Whether $m y$, for instance, is classified as a determiner (LDOCE), an adjective (CULD) or a pronoun (RHD) depends on the part-of-speech system the lexicographer chooses; syntactic categorizations - whether in terms of a simple opposition transitive vs. intransitive (cf. Bergenholtz/Mugdan 1985, 17-20) or a more elaborate coding system (cf. Lemmens/Wekker 1986) - are necessarily based on specific definitions and models. Secondly, the division of labour between Grammar and Dictionary implies that "regular" cases need not be mentioned in the dictionary entries. LDOCE, for instance, shows inflections "only when their written forms or their pronunciations are irregular or when there is a possibility of confusion" (xxii) - but one cannot determine whether a form is "irregular" without first specifying a set of rules that covers the "regular" items.

A dictionary therefore ought to contain some remarks on the theoretical framework and on the rule system upon which the information in the individual entries is based. Ideally, a Grammar that comprises not only "general laws" of grammar in the narrower sense (word classes, inflecti- 
on, derivation and syntax) but also a wide range of other areas (phonetics and phonology, graphemics, morphophonemics, semantics, pragmatics, dialectology, stylistics, language change etc.) should form an integral part of the dictionary (cf. Mugdan in press b). Current practice in lexicography is still far from this ideal. What we do find quite frequently in introductions and appendices are either grammatical sketches that remain unrelated to the body of the dictionary or mere fragments of a Grammar notably lists of inflectional paradigms or sentence patterns that are referred to by numbers or other codes in the entries, e.g. "P 7" for "Subject + Verb + Object + Object Complement (Adjective)" as in We painted the door green (ALD, $\mathrm{xv})$.

Finally, one can give grammatical information by means of specific kinds of lemmas. The following entries from LDOCE illustrate the three most common types, viz. irregular inflected forms (with a cross-reference to the citation form), derivational affixes and parts of compounds ("combining forms"):

Example 2

Explanations of linguistic terms like determiner or transitive also contain information about grammar and possibly about the metalanguage of the dictionary in question (cf. Bergenholtz/Mugdan 1985). In COBUILD, there are even special entries for grammatical codes, e.g. the following one between vomit and voodoo:

Example 3 


\subsection{What purposes can grammatical information serve?}

Dictionaries are normally consulted in the course of either text reception (analysis, decoding) or text production (synthesis, encoding); some tasks - e.g. translation or reading aloud - involve both. In the process of text reception, grammatical information can help the user to find what he is interested in. When he comes across an inflected form like tried or took, he must first determine the corresponding citation form try or take the less familiar he is with the language, the more he will welcome lemmatization rules (e.g. "replace $-i e d$ by $-y$ ") and entries for irregular forms. He may be able to locate the relevant part of the entry more quickly if the articles are subdivided according to syntactic criteria - provided he can identify the construction in which the item occurs. Similarly, homographs that belong to different word classes (e.g. book as a noun or a verb) are often covered in separate entries or subentries.

No dictionary can ever be "complete". Since many of the words that are not listed are derivatives or compounds, information on patterns of word formation and on individual affixes or combining forms may enable the user to determine their meanings, translation equivalents etc. To a limited extent, the user can also rely on such information if he wishes to apply productive word-formation rules and create complex words himself. A far more important problem in text production (especially for the non-native speaker) is the choice of the correct inflected forms and the appropriate syntactic constructions. If the user already has an idea which lexical item he wants to employ, he can consult either a monolingual dictionary or a bilingual one which contains morphological and syntactic information about the source language. (It is therefore not true that a bilingual dictionary in which the lemmas rather than the translation equivalents are accompanied by grammatical comments necessarily serves the "passive" function of text reception, as some authors suggest - cf. Kromann/Riiber/Rosbach 1984, 213-217.) In translating from his mother tongue into a foreign language, he needs a so-called "active" dictionary with grammatical information on the target language.

\section{Current practice in LSP dictionaries}

\subsection{Word classes}

In general monolingual dictionaries, explicit part-of-speech labels are a common feature; they may also be combined with or replaced by indications of gender (in the case of nouns) and transitivity, aspect or conju- 
gation class (in the case of verbs). Sometimes the major open classes (noun, verb, adjective) are left unmarked, especially if they can easily be identified on the basis of the citation forms and/or the other "principal parts" (as in most Slavic languages). While many general bilingual dictionaries indicate the word class of the lemma, there are also quite a few that do not (except perhaps in order to distinguish homonyms), notably if the source language is assumed to be the user's mother tongue. On the target language side, part-of-speech labels are hardly ever used, even if the source word and the translation do not belong to corresponding classes. (For example, the German combining form Büchsen- is equivalent to the English adjective tinned and the French postposed phrase en conserve.)

In LSP dictionaries of all kinds, part-of-speech labels are rather rare. Thus, only one of the four English law dictionaries discussed in Nielsen (1989) makes use of them, and none of the four bilingual ones do. On the whole, however, one is more likely to find information on word classes in bilingual LSP dictionaries. One of those that indicate the class membership of every lemma is a Russian-English medical dictionary (Jablonski 1958):

Example 4

In his forthcoming Danish-English medical dictionary, Pilegaard apparently intends to follow a different principle: His sample entries contain labels for both lemmas and translation equivalents - with the exception of compounds (1988, 242f). No consistent pattern can be discovered in an English-Arabic dictionary of scientific and technical terms (Al-Khatib 1978); while knit, knock out, knock-rating, knotty and knowledge have a label, knob, knocker-out, knotting, know-how and knuckle do not.

Information on word classes is not superfluous, although the authors of most LSP dictionaries seem to think so. Consider, for example, the following excerpt from a dictionary of linguistics (Crystal 1985): 
Example 5

The user cannot know whether fricative is a noun or an adjective until he discovers the phrases fricative sounds and palatal fricative in the middle of the article; in other cases, the explanations do not contain enough evidence: bilabial occurs only as a noun (a non-English bilabial), dental only as an adjective (dental articulation), while interdental is not repeated at all.

Such noun-adjective pairs are quite typical, but many LSP dictionaries list only one of the terms. In one of the Polish dictionaries of linguistics, all the lemmas are nouns or noun phrases (Gohb/Heinz/Polañski 1978): Example 6

These entries leave a number of questions open, e.g.: Are English $e x$ plosive, plosive and occlusive also employed as nouns? Is there no adjective explosiv in German? Does German always use Zahn- and not Dental- in compounds? Dictionaries that do not exclude adjectives on principle may suffer from similar shortcomings: Bußmann (1983) has an entry for diatopisch, but not for other adjectives like ejektiv and implosiv. Instead, we find Ejektiver Laut (with a remark that one can also use the nominalization Ejektiv) and Implosiv(laut) - even though the same pat- 
terns are possible in both cases, viz. adjective + Laut 'sound' (ejektiver Laut, implosiver Laut), nominalization (Ejektiv, Implosiv) or compound (Ejektivlaut, Implosivlaut).

Some lexicographers regularly consider both nominal and adjectival uses but do not employ explicit labels. The following examples come from a medical dictionary (Dorland, pronunciation etc. omitted):

antirheumatic 1. relieving or preventing rheumatism. 2. an agent that relieves or prevents rheumatism.

antiseptic 1. preventing decay or putrefaction. 2. a substance that will inhibit the growth and development of microorganisms without necessarily destroying them.

antithrombotic preventing or interfering with the formation of thrombi; an agent that so acts.

antiulcerative 1. preventing or promoting the healing of ulcers. 2. an agent that so acts.

antiviral 1. destroying viruses or suppressing their replication. 2. an agent that destroys viruses or suppresses their replication.

antivirotic 1. antiviral. 2. an agent that destroys viruses or checks their growth or multiplication.

The systematic indication of word-class membership would have made cross-references easier (cf. antivirotic) and would presumably have led to more consistency and less repetition as well.

\subsection{Gender}

In the case of languages with a gender system, LSP dictionaries frequently label nouns as $m, f$, $n$ etc. even if they do not mark other word classes. $\mathrm{Bi}$ - and multilingual dictionaries normally give this information either for the source language or the target language(s). Polec, a trilingual dictionary of politics and economics, belongs to the former type:

Example 7 
If the user has found a German or French equivalent he is not familiar with, he must look up its gender under the corresponding lemma; a single letter after each translation would have saved him valuable time. Two Danish-German dictionaries, one of law (Gubba 1984) and one of economics (Poulsen 1987), are among those that indicate gender only on the target language side. This is, of course, what the Danish user needs, but speakers of German who are not sure about the gender of a Danish term cannot find the answer here. Sometimes only simple nouns or their equivalents are labelled, as in a multilingual law dictionary (Egbert/MoralesMacedo 1978): Under English sanctuary, one finds French asile ( $m)$; immunité (f), Spanish refugio $(m)$; sanctuario ( $m$ ) and German Asyl (n); Zufluchtsort $(m)$. In the subentry right of sanctuary, however, the equivalents droit d'asile, derecho de asilo and Asylrecht do not have gender labels (although there would have been enough room for them). Since droit, derecho and Recht are equivalents of right, the user can try to look up this word - but such a procedure is inconvenient and need not always work.

\subsection{Inflection}

General dictionaries ordinarily provide a good deal of information on declension and conjugation in the entries as well as in the front or back matter. On the assumption that the user knows certain basic rules, it is, however, frequently restricted to "irregular" cases or to a subset of the paradigm (the "principal parts", such as the genitive singular and nominative plural of German nouns). In bilingual dictionaries, inflectional forms are typically given for one of the languages but not for both. This may be the target language if the dictionary is intended to be used for translations into a foreign language; but there are also numerous dictionaries that give the information for the source language irrespective of the users' native tongue, e.g. for German in the German-English part and for English in the English-German part. While special entries for irregular forms are not uncommon, the need for lemmatization rules is hardly ever recognized.

In most monolingual LSP dictionaries, information on inflection is given only sporadically (e.g. for some borrowings and neo-classical formations) or not at all. For instance, one of the German dictionaries of linguistics (Bußmann 1983) mentions the plurals of Corpus, Lemma and Terminus - but not of all words that pose difficulties, e.g. Adverbiale (-ien or zero?), Allograph (-e or -en?) and Fremdwort (-worte or -wör- 
ter?). Various terms are entered in the plural although the singular forms are perfectly normal; sometimes the latter are incated (e.g. under Abstrakta and Idiotismen) and sometimes not (e.g. under Denominativa and Universalien). General rules for words with characteristic suffixes like -al(e) or -iv(um) would have been helpful, but there seem to be hardly any LSP dictionaries that provide information of this kind. Irregular forms rarely appear as lemmas; in this regard, an English medical dictionary is a laudable exception (Dorland):

Example 8

The authors of bilingual LSP dictionaries often seem to expect that their work will be used in conjunction with a comprehensive general dictionary; Jablonski expressly says so $(1958$, ix). This may be why few of them provide any information on inflection. In a German-English dictionary of art history (Apelt 1982), noun plurals are shown on the lemma side:

$\begin{array}{ll}\text { Buch (Bücher) } n & \text { book } \\ \text { Bucheinband (-bände) } m & \text { binding } \\ \text { Buchrolle(n) } f & \text { scroll, rotulus }\end{array}$

Although the book is likely to be consulted by speakers of German (it was published in Berlin), it fails to indicate the plural of "difficult" English nouns like rotulus. Some dictionaries of the "active" type specify inflectional properties of the translation equivalents. For example, Poulsen (1987) gives the genitive singular and nominative plural of German nouns and marks those verbs that are irregular ("strong"):

$\begin{array}{ll}\text { storbedrift } & \text { Großbetrieb, der; -(e)s, -e } \\ \text { varemesse } & \text { Messe, die; -, -n } \\ \text { checke } & \text { checken, nachprüfen, kontrollieren } \\ \text { opdrive (varer) } & \text { auftreiben } / \text { st/ } \\ \text { stille om (telefon) } & \text { verbinden } / \text { st/, umstellen }\end{array}$

However, the dictionary does not contain a verb list in which the user could find the forms of (auf)treiben and (ver)binden. He also has to rely on other sources if he does not know whether the past participle is formed 
with or without ge- (cf. gecheckt, nachgeprüft, kontrolliert, aufgetrieben, verbunden, umgestellt). Another "active" Danish-German dictionary that has gender labels and syntactic information on the German side says nothing about inflection (Gubba 1984).

\subsection{Word formation}

With regard to entries for affixes and combining forms, current practice in general dictionaries varies considerably. If such elements are included, it is often far from clear on what grounds they were selected; there seem to be certain tendencies to prefer affixes to combining forms, prefixes to suffixes and neo-classical elements to native ones. In LSP lexicography, the situation is not much different. The elements most likely to be listed are, of course, the building blocks of highly systematic nomenclatures, such as that of medicine (Dorland):

Example 9

Similarly, one will normally find lemmas like ferro- and -ide in chemical dictionaries (e.g. Bennett 1986). There are also some bilingual dictionaries that give translation equivalents for affixes and combining forms (e.g. Jablonksi 1958). In addition to such entries, several medical dictionaries (including Dorland) contain an introduction to the structure of medical vocabulary and a list of the most common Greek and Latin components.

In dictionaries for the humanities or the social sciences, word formation plays a very minor role, as a quick test demonstrates: I looked up allo-, -eme, -fix, homo-, -lect and proto- (or their equivalents) in a dozen dictionaries of linguistics. Four of them did not contain any of these elements. In the remaining ones, allo- occurred six times, proto- and -eme four times each (counting one instance of -emisch); only two dictionaries gave all three items. None of them had entries for -fix, homo- or -lect (one listed lect as a noun). 


\subsection{Syntax}

The amount of syntactic information in general monolingual dictionaries depends on whether they are meant to be used by native speakers or by foreign learners. The former are widely - erroneously - believed to need little or no help, while strong emphasis on syntax is one of the outstanding characteristics of learners' dictionaries (cf. 1.1). Bilingual dictionaries occupy an intermediate position: Many of them do contain a lot of information on constructions, but it tends to be less systematic and less clear than in learners' dictionaries; to a large extent, it must be derived from examples that are not always unambiguous (cf. Herbst 1985).

In the majority of LSP dictionaries, syntax is entirely neglected. A few indications of government etc. can be found on the German side of the Danish-German law dictionary mentioned before (Gubba 1984):

acceptere [...] 4 (tage til følge) - stattgeben (D)

forskud Vorschuß m.; [...] modtage $\sim$ på ... - auf ... (A) einen Vorschuß erhalten lov Gesetz n. (über + A)

Poulsen (1987) sometimes shows the corresponding constructions in both languages:
opgivelse (af) [...]
1. Angabe $[\ldots](+$ Gen, über $+A k k$, von + Dat $)$
opgøre
1. opgøre (beregne) (til)
1. berechnen (auf $+A k k)$
ophøre
2. ophøre med at
2. aufhören $\mathrm{zu} /+$ infl

In other cases (which do not appear to be substantially different), the syntactic information is confined to the German side:

omsætning

1. alm

1. Umsatz [...] $($ an + Dat, in + Dat $)$

stille

3. stille spørgsmål

vedblive (fortsatte)

3. (jmdn etw) fragen, (jmdm) eine Frage stellen

fortfahren [...] mit /+ Dat/ eller zu /+ inf/

\section{Suggestions}

\subsection{Word class and gender}

Part-of-speech labels are admittedly not very informative, but their value increases if the word classes are defined in a clear and comprehensible fashion. For the major open classes, morphological criteria will normally be most appropriate, whereas the closed classes are better delimited on a syntactic basis. The system used by the lexicographer should be 
explained in the dictionary so that the user knows exactly what the labels mean.

In bilingual dictionaries for languages with fairly similar part-of-speech systems, it is sufficient to indicate the word class of the lemma unless the equivalent does not belong to the corresponding class. If there are considerable discrepancies between the systems, different sets of labels should be used on the two sides.

Homonyms that belong to different classes should always be assigned to separate entries or subentries; an explicit label should be provided in order to make the distinction more transparent. Great care should be taken to indicate all instances of structural homonymy, especially between nouns and adjectives.

If nouns fall into different genders, it is advisable to use specific labels for these instead of a general one for nouns. In the interest of the user, the gender of all nouns (including compounds) should be marked. One can, however, save space by stating a few basic rules. In German, for instance, words that end in - $e$ or that have the suffix -ung can be assumed to be feminine unless otherwise indicated. If there are only two genders (as in French or Danish), one of them could be left unmarked.

\subsection{Inflection}

LSP dictionaries should provide comprehensive information on inflection if the language in question is not the user's native tongue; he should not be forced to consult a general dictionary in addition. It is important to bear in mind whether the dictionary is meant to be used for encoding or for decoding. The traditional method of listing the "principal parts" or giving the number of a model paradigm is suitable for translations into a foreign language but not for text reception. The latter can be greatly facilitated if the dictionary tells the user how to get from an oblique form (in the text) to the citation form (in the dictionary). Entries for irregular forms are needed wherever these rules do not apply. For the purpose of text production, the information in the entries should also be supplemented by general rules so that highly frequent and predictable patterns need not be indicated in every single case. If only certain "principal parts" are given in the entries, one should not forget to explain how the remaining forms can be derived.

Native speakers will primarily want information on the inflection of borrowings and neo-classical terms. The forms of well-known native words need not be mentioned unless LSP usage deviates from the stan- 
dard language. Certain general tendencies should be pointed out in the introduction, e.g. the use of sortal plurals like honeys. If the proportion of neo-classical terms is rather high, a brief sketch of Latin (and perhaps Greek) morphology might be helpful. Its scope will have to depend on the characteristics of the LSP variety. In a medical dictionary, for instance, it would be sufficient to discuss the nominative and genitive singular and plural of nouns and adjectives; in other disciplines, the only point of interest may be plural formation.

It is a fundamental principle of bilingual lexicography that the user should be given more help with the language he knows less well. This implies, for example, that a Danish-German dictionary for Danish users ought to be quite different from one for German users (cf. Kromann/Riiber/Rosbach 1984): The speaker of Danish requires a great deal of grammatical information about the German equivalents in order to be able to employ them correctly in his translation, while the speaker of German needs information about the Danish lemmas - not only if he wants to decode a Danish text but also if he tries to express himself in Danish without a German model. (Many lexicographers overlook that grammatical comments on the source language should serve this double role, especially if no monolingual learners' dictionary is available; cf. 1.3.) Unfortunately, it is often not feasible to produce separate dictionaries for the two groups of users - especially in LSP lexicography. If a dictionary is to be bifunctional, i.e. suitable for speakers of either language (cf. Kromann/ Riiber/Rosbach in press, §2.1), it must provide grammatical information on both sides.

\subsection{Word formation}

Languages for special purposes are very rich in compounds and derivatives, not all of which can be listed in a dictionary. Entries for affixes and combining forms with detailed explanations of their meanings and functions are therefore of great importance, particularly from the point of view of text reception. During text production, the user should be a little careful about creating words from components he knows - the combination may be grammatical but just not used. Many patterns are, however, fully productive, and this should be mentioned in the dictionary.

If there are rigid rules for the formation of certain terms, they should be stated in the introduction, particularly if national or international standards have to be observed (e.g. in medical and chemical nomenclature). In the absence of explicit norms, there may still be generally recognized 
conventions, e.g. concerning the order of constituents in compounds and fixed phrases (cf. voiceless velar fricative and not ${ }^{*}$ fricative voiceless velar in phonetics). Another interesting point is that various languages for special purposes show strong preferences for patterns of word formation that are quite rare in the standard language (e.g. German compound verbs like trennschleifen from trennen 'separate' and schleifen 'grind').

\subsection{Syntax}

Information on the combinations into which a lexical item can enter ("valency", government, collocations etc.) is relevant for text production in a language the user is not sufficiently familiar with. This need not necessarily be a foreign language in the traditional sense - to students and interested laymen, for instance, the LSP varieties they are confronted with are also "foreign". The amount of information that should be given depends on the characteristics of the particular variety; presumably, some languages for special purposes (e.g. those of law and commerce) have more syntactic pecularities than others (e.g. the nomenclatures of the sciences).

As regards bilingual dictionaries, the principles mentioned in 3.2 are also valid here. Instead of having to consult a general dictionary or a grammar, the user should be able to find the information he needs in a single book. His native language and the purposes for which he uses the dictionary are the criteria that determine what information should be given and where.

Although languages for special purposes normally make use of the same syntactic patterns as the standard language, the frequency of certain constructions may be quite different; the preference for passives or for the so-called "nominal style" are well-known examples. Sometimes, functional differences that are not strictly observed in the standard language may acquire special significance (cf. Poulsen 1988, 33-35 on indirect speech in legal texts), and there are often rather rigid conventions concerning the structure of specific types of texts. A few remarks on such phenomena (which are, of course, on the borderline between syntax and stylistics) would certainly enhance the value of an LSP dictionary.

\subsection{Conclusion}

In recent years, the making of dictionaries has attracted a great deal of interest. Analyses of the users' needs led to a reappraisal of current practice, and user-friendliness became a favourite word of linguists and lexi- 
cographers. One of the areas where they noted many deficits was grammatical information. In a number of general monolingual and bilingual dictionaries, new ideas were applied, and various suggestions for further improvements can be found in the rapidly growing literature. LSP lexicography, however, still lags behind - although the arguments in favour of grammatical information hold for LSP dictionaries, too, and the principles that have already been developed for general dictionaries can be applied with minor modifications. But, hopefully, the times are a-changin' ...

\section{Literature}

\subsection{Dictionaries}

$\mathrm{ALD}=\mathrm{A}$. S. Hornby / E. V. Gatenby / H. Wakefield: A Learner's Dictionary of Current English. London: Oxford University Press 1948.

Al-Khatib, Ahmed (1978): A New Dictionary of Scientific and Technical Terms. EnglishArabic. 4th ed., Beirut: Librairie du Liban 1978.

Apelt, Mary L. (1982): German-English Dictionary: Art History - Archaeology / Deutsch-Englisches Wörterbuch für Kunstgeschichte und Archäologie. Berlin: Erich Schmidt.

Bennett, H. (1986) (ed.): Concise Chemical and Technical Dictionary. 4th ed., London: Arnold.

Bußmann, Hadumod (1983): Lexikon der Sprachwissenschaft. Stuttgart: Kröner.

COBUILD = Collins COBUILD English Language Dictionary. Editor in Chief: John Sinclair, Managing Editor: Patrick Hanks. London, Glasgow: Collins 1987.

Crystal, David (1985): A Dictionary of Linguistics and Phonetics. 2nd ed., Oxford: Blackwell / London: Deutsch.

CULD = E M Kirkpatrick (ed.): Chambers Universal Learners' Dictionary. Edinburgh: Chambers 1980.

Dorland $=$ Dorland's Illustrated Medical Dictionary. 26th ed., Philadelphia etc.: Saunders 1981.

Egbert, Lawrence Deems / Morales-Macedo, Fernando (1978): Multilingual Law Dictionary. English - Français - Español - Deutsch. Alphen a.d.R.: Sijthoff / Dobbs Ferry NY: Oceana / Baden-Baden: Nomos.

Golab, Zbigniew / Heinz, Adam / Polañski, Kazimierz (1970): Slownik terminologii jezykoznawczej. Wyd. 2, Warszawa: Panstwowe Wydawnictwo Naukowe.

Gubba, Wilhelm (1984): Juridisk ordbog dansk-tysk. 2. udgave, Mårslet: Gubba 1984.

Jablonski, Stanley (1958): Russian-English Medical Dictionary. Edited by Ben. S. Levine. New York: Academic Press.

LDOCE = Longman Dictionary of Contemporary English. Editor-in-Chief: Paul Procter, Managing Editor: Robert F. Ilson. Harlow: Longman 1978.

polec $=$ Back, Harry / Cirullies, Horst / Marquard, Günter: polec . Dictionary of politics and economics / Dictionnaire de politique et d'économie / Lexikon für Politik und 
Wirtschaft. 2. Aufl., Berlin: de Gruyter 1967.

PONS E-D = Roland Breitsprecher / Veronika Calderwood-Schnorr / Peter Terrell / Wendy V. A. Morris: Pons-Globalwörterbuch English-Deutsch / Collins English-German Dictionary. Stuttgart: Klett / London, Glasgow: Collins 1983.

Poulsen, Sven-Olaf (1987): Dansk-tysk handelsordbog. 4. udgave, Harlev: Kjær 1987.

RHD = The Random House Dictionary of the English Language. Editor in Chief: Jess Stein, Managing Editor: Laurence Urdang. New York: Random House 1967.

\subsection{Other Publications}

Bergenholtz, Henning (1984a): "Grammatik im Wörterbuch: Wortarten", in: Herbert Ernst Wiegand (ed.): Studien zur neuhochdeutschen Lexikographie IV. Hildesheim, Zürich, New York: Olms 1984, 19-72. (= Germanistische Linguistik 1-3/83)

Bergenholtz, Henning (1984b): "Grammatik im Wörterbuch: Syntax", in: Herbert Ernst Wiegand (ed.): Studien zur neuhochdeutschen Lexikographie V. Hildesheim, Zürich, New York: Olms 1984, 1-46. (= Germanistische Linguistik 3-6/84)

Bergenholtz, Henning / Mugdan, Joachim (1985): "Linguistic Terms in German and English Dictionaries", in: Lexicographica 1, 1985, 3-23.

Hausmann, Franz Josef / Reichmann, Oskar / Wiegand, Herbert Ernst (in press) (eds.): Wörterbücher - Dictionaries - Dictionnaires. Ein internationales Handbuch zur Lexikographie - International Encyclopedia of Lexicography - Encyclopédie internationale de lexicographie. Berlin, New York: de Gruyter.

Herbst, Thomas (1985): "Das zweisprachige Wörterbuch als Schreibwörterbuch: Informationen zur Syntax in zweisprachigen Wörterbüchern Englisch-Deutsch/ DeutschEnglisch", in: Henning Bergenholtz / Joachim Mugdan (eds.): Lexikographie und Grammatik. Akten des Essener Kolloquiums zur Grammatik im Wörterbuch 28.30.6.1984. Tübingen: Niemeyer 1985, 308-331.

Jackson, Howard (1985): "Grammar in the Dictionary", in: Robert Ilson (ed.): Dictionaries, Lexicography and Language Learning. Oxford etc.: Pergamon Press 1985, 5359.

Kromann, Hans-Peder / Riiber, Theis / Rosbach, Poul (1984): "Überlegungen zu Grundfragen der zweisprachigen Lexikographie", in: Herbert Ernst Wiegand (ed.): Studien zur neuhochdeutschen Lexikographie V. Hildesheim, Zürich, New York: Olms 1984, 159-238. (= Germanistische Linguistik 3-6/84)

Kromann, Hans-Peder / Riiber, Theis / Rosbach, Poul (in press): "Principles of bilingual lexicography", in: Hausmann/ Reichmann/Wiegand (in press).

Lemmens, Marcel / Wekker, Herman (1986): Grammar in English Learners' Dictionaries. Tübingen: Niemeyer 1986.

Mugdan, Joachim (1983): "Grammatik im Wörterbuch: Flexion", in: Herbert Ernst Wiegand (ed.): Studien zur neuhochdeutschen Lexikographie III. Hildesheim, Zürich, New York: Olms 1983, 179-237. (= Germanistische Linguistik 1-4/82)

Mugdan, Joachim (1985a): "Grammatik im Wörterbuch: Wortbildung", in: Herbert Ernst Wiegand (ed.): Studien zur neuhochdeutschen Lexikographie IV. Hildesheim, Zürich, New York: Olms 1984, 237-308. (Germanistische Linguistik 1-3/83)

Mugdan, Joachim (1985b): "Pläne für ein grammatisches Wörterbuch. Ein Werkstatt- 
bericht", in: Henning Bergenholtz / Joachim Mugdan (eds.): Lexikographie und Grammatik. Akten des Essener Kolloquiums zur Grammatik im Wörterbuch 28.30.6.1984. Tübingen: Niemeyer 1985, 187-224.

Mugdan, Joachim (in press a): "Information on Inflectional Morphology in the General Monolingual Dictionary", in: Hausmann/Reichmann/Wiegand (in press), 518-525.

Mugdan, Joachim (in press b): "Grundzüge der Konzeption einer Wörterbuchgrammatik", in: Hausmann/Reichmann/Wiegand (in press), 732-749.

Nielsen, Sandro (1989): "Kritisk oversigt over engelske og danske juridiske ordbøger", in: Hermes 2, 1989, 55-75.

Pilegaard, Morten (1988): "Dansk-engelsk medicinsk ordbog", in: Hermes 1, 1988, 239244.

Poulsen, Sven-Olaf (1988), "Problemer omkring beskrivelsen af modusbrugen i tysk 'indirekte tale'", in: Hermes 1, 1988, 25-36.

Sweet, Henry (1892): A New English Grammar Logical and Historical, Part I: Introduction, Phonology, and Accidence. Oxford: Oxford University Press 1892. 